\title{
TOURISM AS A COMPONENT OF THE SEA COMPLEX OF UKRAINE
}

\author{
Savelieva I. V., Semenov V. F., Ivanov A. M.
}

\section{INTRODUCTION}

The national economy of Ukraine is experiencing a difficult period of systemic changes, which is accompanied by a crisis of the socio-political system, a catastrophic decline in economic growth and increasing negative trends in all spheres of life. On the way to overcoming these difficulties, the state should focus its efforts on realizing its advantages in the global division of labor, find ways to make the most efficient use of the resource base and unique geographical location.

The maritime economical complex (MEC) can play an important role in the socio-economic development of the country. For Ukraine, the formation of a competitive MEC can be a turning point in economic reforms, basis for strategic development and promote the state at the global level. This requires ensuring dynamic innovative development of all sectors of the maritime complex of the state, full functioning of coastal zones, restructuring of coastal areas, reproduction of maritime infrastructure and efficient navigation, as well as providing all components of the complex with highly educated professionals.

Therefore, the problem of developing theoretical, methodological principles and practical recommendations for the modernization of the MEC of Ukraine at the state and regional levels is becoming important for both the state and the average citizen of Ukraine.

Theoretical and practical aspects of the development of maritime activities and the MEC have been considered in many works of domestic and foreign scientists. Among the most important foreign scientists, whose works have studied the formation of the maritime industry, include: D. Gamble, J. Williams, I. Lewis, R. Dole, A. Jacobson. The problems of determining the features of maritime economic activity have been studied in the works of A. S. Averkov, V. S. Bondarenko, M. R. Kononenko, M. I. Kraev, S. B. Saveliev, M. B. Shilin.

Ukrainian scientists V. G. Chekalovets, M. T. Primachev, M. I. Kotlubay, O. M. Kotlubay, O. M. Kibik, V. V. Zhikhareva, V. O. Dergachev and others made a significant contribution to the development of the MEC.

The teaching staff of the Department of "Entrepreneurship and Tourism" of Odessa National Maritime University focuses his efforts within the system of 
global scientific research of the MEC at studying of the theoretical aspects of the tourist component of the MEC and the role of tourism in the maritime cluster. Thus, the works of V. F. Semenov ${ }^{1,2,3,4,5,6,7}$ were devoted to substantiation of the effectiveness of the cluster model in the regional development of tourism, scientific works of O. M. Kotlubay ${ }^{89}$ were focused on the formation of maritime doctrine, competitiveness and sustainable development of the maritime complex, scientific works of V. O. Dergachev ${ }^{10}$ were devoted to the influence of geopolitics at the MEC and tourism as its component, the economic aspects of cruise tourism development are studied in the works of I. V. Savelieva and Yu. V. Mikhailova ${ }^{11,12,13}$. A. M. Ivanov's

${ }^{1}$ Semenov V. F., Bilegha O. V. (2014) Konkurentni perevaghy merezhevykh struktur klasternogho typu [Competitive advantages of cluster-type network structures]. Odesa: Atlant VOISOIU, pp. 236. (in Ukrainian)

${ }^{2}$ Semenov V. F., Basjuk O. V. (2014) Terytorialjni umovy i strateghiji rozvytku turyzmu v reghionakh [Territorial conditions and strategies for the development of tourism in the regions]. Odesa: Visnyk ONU im. I. I. Mechnikova, no. 19 (1/2), pp. 78-81. (in Ukrainian)

${ }^{3}$ Semenov V. F. (2010) Klasterna polityka v upravlinni reghionaljnym rozvytkom turyzmu [Cluster policy in the management of regional tourism development]. Odesa: Visnyk socialjno-ekonomichnykh doslidzhenj, no. 40, pp. 56-63. (in Ukrainian)

4 Semenov V. F., Mozghaljova V. M., Davydenko I. V. (2006) Reghionaljnyj rekreacijnyj klaster u konteksti strukturnoji perebudovy ekonomiky [Regional recreational cluster in the context of structural perestroika economy]. Odesa: Reghionaljna ekonomika, no. 3 , pp. 78-89. (in Ukrainian)

${ }^{5}$ Semenov V. F. (2008) Reghionaljna ekonomika [Regional economics]. Kyiv : Lesja. (in Ukrainian)

${ }^{6}$ Semenov V. F. (2010) Klasterna polityka v upravlinni reghionaljnym rozvytkom turyzmu [Cluster policy in the management of regional tourism development]. Odesa: Visnyk socialjno-ekonomichnykh doslidzhenj, no. 40, pp. 52-57. (in Ukrainian)

${ }^{7}$ Kotlubaj O. M. (2015) Portovyj kompleks Ukrajiny: problemy i perspektyvy rozvytku [Port complex of Ukraine: problems and prospects of development]. URL: http://www.2000.ua/vnomere/derzhava/resursy/portovij-kompleks-ukraini-b3-1-b4_144 0057128.htm (accessed 28 May 2020).

${ }^{8}$ Kotlubaj A. M. (2008) Torgovoe sudokhodstvo Ukrainy: problemy i perspektivy [Merchant shipping of Ukraine: problems and prospects]. Odessa : IPRI NAN Ukrainy, pp. 256. (in Ukrainian)

9 Dergachev V. A. (2004) Geopolitika [Geopolitics]. Moscow: YuNITI-DANA (in Russian)

${ }^{10}$ Savelieva I. V. (2019) Rozvytok krujiznogho turyzmu v umovakh vykorystannja metodyky smart-specializaciji Odesjkoji oblasti [Development of cruise tourism in the conditions of using the technique of smart specialization of Odessa region]. Odessa : Rozvytok metodiv upravlinnja ta ghospodarjuvannja na transporti, no. 4(69), pp. 5-14. (in Ukrainian) (DOI: https://doi.org/10.31375/2226-1915-2019-4-5-14)

${ }^{11}$ Mykhajlova Ju. V. (2012) Otsenka privlekatel'nosti portov zakhoda v kruiznom marshrute [Assessment of the attractiveness of ports of call on a cruise route]. Odessa : Rozvytok metodiv upravlinnja ta ghospodarjuvannja na transporti, no. 14, pp. 113-128. (in Ukrainian) 
works are devoted to ecological aspects and problems of land relations in the sphere of tourism and recreation as well as institutional bases of interaction of subjects of the market of sea cruise tourism ${ }^{14,15,16,17,18}$ researches of A. M. Kholodenko and S. V. Melnikov are devoted to economic and mathematical methods and models of management of development of sea transport ${ }^{19,20}$ concepts of clusters on maritime transport were studied by N. G. Grebennik ${ }^{21,22}$ quality system and its management in the sphere of tourism activity were reviewed by Yu. O. Navrozova ${ }^{23,24}$.

12 Mykhajlova Ju. V. (2013) Vliyanie morskoy turisticheskoy renty na formirovanie dokhodov kruïznogo operatora [Vliyanie morskoy turisticheskoy renty na formirovanie dokhodov kruïznogo operatora]. Odessa: Rozvytok metodiv upravlinnja ta ghospodarjuvannja na transporti, no. 1(20), pp. 28-45. (in Ukrainian)

13 Ivanov A. M. (2012) Upravlinnja konkurentospromozhnistju rekreacijnoozdorovchogho zemlekorystuvannja [Management of the competitiveness of recreational and health-improving land use]. Mykolajiv: Dyzajn ta Polighrafija, pp. 248. (in Ukrainian)

${ }^{14}$ Ivanov A. M. (2018) Instytucionaljni aspekty rekreacijnogho zemlekorystuvannja [Institutional aspects of recreational land use]. Lucjk: Ekonomichnyj forum, no. 2, pp. 178-182. (in Ukrainian)

15 Ivanov A. M. (2013) Osoblyvosti upravlinnja rekreacijno-ozdorovchymy pidpryjemstvamy $\mathrm{V}$ systemi turystychnogho klasteru [Features of management of recreational and health-improving enterprises in the system of tourist cluster]. Odessa: Ekonomika pishchevoy promyshlennosti, no. 4(20), pp. 12-17. (in Ukrainian)

${ }^{16}$ Ivanov A. M. (2018) Shljakhy udoskonalennja instytucionaljnogho mekhanizmu rekreacijno-turystychnoji polityky Ukrajiny [Shljakhy udoskonalennja instytucionaljnogho mekhanizmu rekreacijno-turystychnoji polityky Ukrainy]. Kherson: Biznes-navighator, no. 1(44). pp.72-76. (in Ukrainian)

17 Ivanov A. M. (2019) Instytucionaljni zasady vzajemodiji sub'jektiv rynku morsjkogho krujiznogho turyzmu [Institutional principles of interaction between the subjects of the maritime tourism market]. Odessa : Development of methods of management and administration of transport, no.3(68), pp. 100-112. (in Ukrainian) (DOI: https://doi.org/10.31375/2226-1915-2019-3-97-107).

18 Kholodenko A. M. (2002) Modeljuvannja cinovoji konkurenciji transportnykh pidpryjemstv $\mathrm{u}$ loghistychnij systemi [Modeling of price competition of transport enterprises in the logistics system]. Kharkiv: KhNADU, no. 5, pp. 37-41. (in Ukrainian)

19 Kholodenkko A. M., S. V. Meljnykov (2006) Taryfnoe reghulyrovanye loghystycheskoj cepochky postavok [Tariff regulation of the supply chain]. Odesa: Metody ta zasoby upravlinnja rozvytkom transportnykh system, no. 11, pp. 17-40. (in Ukrainian)

${ }^{20}$ Ghrebenyk N. Gh. (2008) Koncepcyja klasterov na morskom transporte [The concept of clusters on maritime transport]. Odesa: Rozvytok metodiv upravlinnja ta ghospodarjuvannja na transporti, no. 8, pp. 86-93. (in Ukrainian)

21 Ghrebenyk N. Gh. (2013) Osnovy realizatsii klasternoy kontseptsii v morekhozyaystvennom komplekse Ukrainy [Basics of the implementation of the cluster concept in the maritime complex of Ukraine]. Odesa: Rozvytok metodiv upravlinnja ta ghospodarjuvannja na transporti, no. 1(42), pp. 45-55. (in Ukrainian) 
Based on the results of last five years of studies in the framework of budget-funded and commercial researches of the Department of "Entrepreneurship and Tourism" of Odessa National Maritime University, we summarize the role and place of tourism in the MEC of Ukraine and prospects of this socio-economic activity clustering in the framework of the implementation of the Maritime Doctrine of Ukraine for the period up to $2035^{25}$.

\section{SPATIAL APPROACH TO UNDERSTANDING THE MARITIME COMPLEX}

As stated in the Maritime Doctrine of Ukraine for the period up to 2035, at the present stage of development the factor of Ukraine's establishment as a maritime state reaches special significance, the preconditions of which are its spatial and geophysical features, place and role in global and regional systems of international relations.

Ukraine has the largest length of the sea coast $(2759.2 \mathrm{~km})$ among the states of the Azov-Black Sea basin and more than 72 thousand square kms of exclusive maritime economic zone ${ }^{26}$. A significant part of the national gross domestic product is formed by five littoral regions, which occupy about $27 \%$ of its territory. The majority of the population in this area lives at a distance of no more than $60 \mathrm{~km}$ from the sea and is closely linked to maritime activities ${ }^{27}$. That is why the MEC plays an important role in ensuring economic stability and development of the state.

22 Navrozova Ju. O. (2004) Metody upravlenyja kachestvom portovoj produkcyy [Methods of quality management of port products]. Odesa: Rozvytok metodiv upravlinnja ta ghospodarjuvannja na transporti, no. 18, pp. 70-83. (in Ukrainian)

${ }^{23}$ Navrozova Ju. O. (2017) Upravlinnja vytratamy na jakistj jak skladova koncepciji strateghichnogho upravlinnja vytratamy portovogho operatoru [Quality cost management as a component of the concept of strategic cost management of the port operator]. Kharkiv: Problemy i perspektyvy rozvytku pidpryjemnyctva, no. 3(2), pp. 31-36. (in Ukrainian)

${ }^{24}$ Morsjka doktryna Ukrajiny na period do 2035 roku (2016) [Maritime Doctrine of Ukraine for the period up to 2035]. URL: http://sudostroy.com/category/morskaja-doktrinaukrainy/ (accessed 29 May 2020).

${ }^{25}$ Ministerstvo vnutrishnikh sprav posyljuje robotu svojikh pidrozdiliv na diljanci AzovoChornomorsjkogho basejnu [The Ministry of Internal Affairs strengthens the work of its units in the Azov-Black Sea basin]. URL: http://www.ukrinform.ua/rubric-ato/2686515-mvs-posilueprisutnist-v-azovskomu-ta-cornomu-morah.html (accessed 29 May 2020).

26 Velyke perebalansuvannja [Great rebalancing]. URL: https://tyzhden.ua/ Economics/234522 (accessed 29 May 2020).

27 Volosjuk M. V., Vdovychenko L. Ju. (2016) Funkcionaljna struktura moreghospodarsjkogho kompleksu Ukrajiny [Functional structure of the maritime economic complex of Ukraine]. Kharkiv: Biznes Inform, no. 2, pp. 14-20. (in Ukrainian) 
The MEC consists of many types of economic activity, which play a key role in the formation of various products and services, creating opportunities to meet the diverse needs of the economy. Most scientific approaches to the interpretation of the concept of "maritime complex" include tourism, recreation, and in some cases the hotel and restaurant business, which allows us to conclude about the importance of tourism in the structure of the MEC. Thus, S. B. Savelyeva, A. M. Savelyev and I. V. Kozynsky believe that recreation is one of the 3 main components of the MEC, and Yu. V. Malinina believes that sea recreation (sea tourism, health and medical activities on the coast) is one of the 6 sectors of the maritime complex. G. G. Gogoberidze believes that one of the basic principles of defining the spheres of the maritime economy is tourism. O. M. Kibik, O. P. Podtserkovny and V. O. Kotlubay asserted that one of the main activities of the MEC is "maritime transport activities (on the implementation of passenger transport by sea)". The importance of the tourism segment for the development of the MEC of Ukraine is confirmed by Maritime doctrine, which states that the formation of a competitive market for tourism, recreational, health services and cruise shipping in coastal regions, their integration with other maritime activities is a priority of national and regional governments and indicates the direct relation of these activities to the marine industry ${ }^{28}$. That is why tourism in the maritime economic zone should be included in the maritime complex.

It should be noted that the level of use of the potential of the maritime complex of Ukraine is not entirely satisfactory and does not meet the national interests of the state. Recently, there has been an extremely rapid reduction of the national fleet, loss of Ukraine's leading position in passenger transport, reduction of domestic export and import cargo on Ukrainian ships, deterioration of fixed assets of the MEC of Ukraine, inconsistency of port management system with modern priorities, absence of the focused and sustained activity of the MEC development at the level of public authorities.

But despite the above problems, the potential of the MEC of Ukraine is very significant and potentially important for the development of the national economy. The main components of the MEC potential are given in Fig. 1.

Based on the existing potential of the MEC, we can say that by pursuing an effective economic policy aimed at developing each component of its multilevel and multifunctional structure, it is possible to increase the level of competitiveness of the whole complex.

${ }^{28}$ Ivanov A. M. (2018) Innovacijna dijaljnistj jak skladova konkurentospromozhnosti pidpryjemstv restorannogho ghospodarstva [Innovative activity as a component of competitiveness of restaurant enterprises]. Proceedings of the Jevropejsjka integhracija: istorychnyj dosvid ta ekonomichni perspektyvy, Odesa: ONU im. I. Mechnykova, pp. 44-46. 


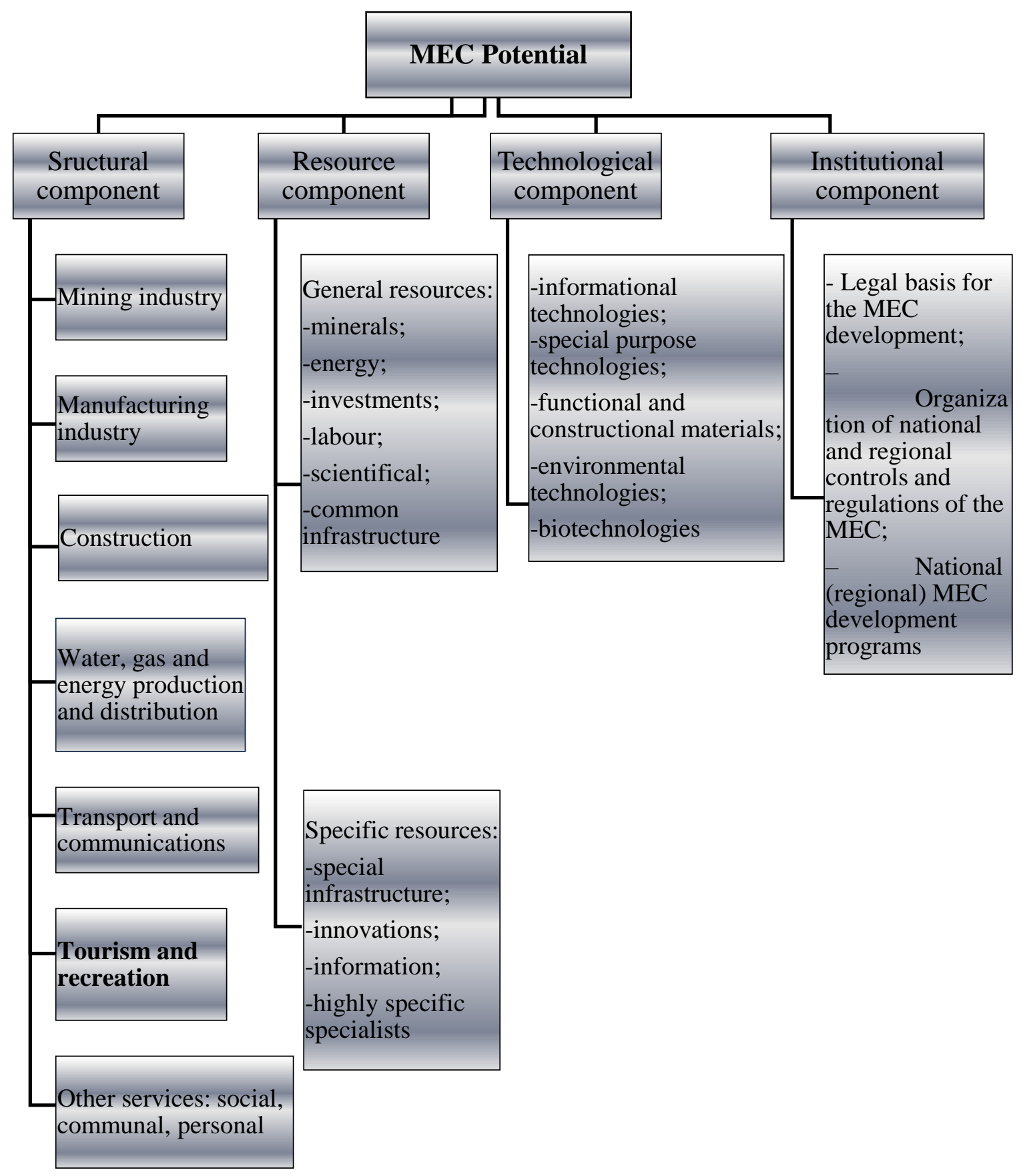

Fig. 1. The main components of the MEC potential

Source: based on ${ }^{29}$

Today, the world maritime countries are implementing a strategy of economic growth and a number of systematic measures aimed at increasing the competitiveness of the MEC economic space: supporting local coastal fisheries organizations, establishing effective influence on the management of aquatic

${ }^{29}$ Kotlubaj O. M. Ekonomichni mekhanizmy rozvytku torghiveljnogho moreplavannja v Ukrajini [Economic mechanisms for the development of merchant shipping in Ukraine]. Odesa: IPREE D NAN Ukrajiny, pp. 453. (in Ukrainian) 
biological resources to ensure access for future generations; actively developing and implementing new technologies for the artificial reproduction of marine reserves and the development of mineral and energy resources of the oceans; the transition to the introduction of innovative technologies in shipbuilding and marine instruments, production, processing and transportation of energy resources of the continental shelf, as well as restrictions on their export; information support of maritime activity with the use of modern means of navigation and communication is being developed ${ }^{30}$.

This spatial aspect of the problems allows us to take into account the dual nature of the MEC - aquatorial and territorial, which, on the one hand, divides it into two independent economic activities, and on the other - interconnects them into a single system with synergistic potential. It is this postulate that helps to form a methodological approach to the functioning of the MEC as a holistic spatial system and to analyze its development from the standpoint of the spatial economy. In the context of the spatial approach, the landside littoral area of the MEC is a part of its seaside coastal zone along with inland waters, territorial waters, the exclusive economic zone and the continental shelf.

According to the results of many years of research, Odessa National Maritime University scientists have formed and developed a scientifically significant concept of spatial economics, which provides a synthetic description of spatial research, based on the axiomatic postulate: all economic activity in the country takes place in a particular area and its resources. Potential, structure of the economy, financial-banking and settlementanalytical components, the sphere of services together with tourism and recreation, settlement system, markets, their configuration, spatial and historical expansion and the level of urban development are the starting points and specialists must know them thoroughly. Especially those that create strategies for the development of the state as a whole, as well as its parts, including the MEC of the coastal regions of Ukraine.

The problems of the MEC organization are the most important for the functioning of its economic space. Given that the spatial organization of material production and services has both spontaneous and purposeful nature, there are many areas of its study. As O. G. Granberg rightly points out, in the history of knowledge of economic space after the ancient philosophers (Aristotle, Plato), utopists (T. More, R. Owen) and the first classics of economics of the XVII-XVIII centuries (A. Smith, D. Ricardo) for a long time was mostly calm - the simplified concept of "closed country without dimensions" prevailed, i.e. the interaction of production factors, distances and transport costs, immobility of natural resources, competitive advantages of

${ }^{30}$ Granberg A. G. (2004) Osnovy regional'noy ekonomiki [Fundamentals of regional economy]. Moscow: GU VShE, S. 41. (in Russian) 
certain places of production were not taken into account ${ }^{31}$. Such simplified approaches were violated only in the XIX-XX centuries by the placement theories of J. Thünen, W. Laundhardt, A. Weber, A. Lösch, W. Isard and many other researchers who created a new scientific field of "regional science", which today is rapidly evolving and becoming a fundamental synthetic branch of global science, which has a systematic approach to the space inhabited by men.

\section{TOURIST AND RECREATIONAL COMPLEX AS A COMPONENT OF THE MARITIME COMPLEX}

Among the numerous measures for the formation of a competitive domestic maritime complex a significant place belongs to the development of tourism-recreational complex (cruise, ecological, cultural-cognitive, pilgrimage, scientific and scientific-expeditionary, extreme, sports, medical, health tourism, etc.). The MEC's tourism-recreational complex is a basic model, which consists of interconnected economic and social systems (blocks), such as: natural and cultural-historical potential, vacationers, tourist infrastructure, service personnel, management and regulatory bodies.

On the one hand, the development of tourism and recreation was preceded and facilitated by their environmental purpose, on the other - the conscious neglect of this area negatively affected its economic performance and created pressure on local and national budgets, due to which (in most cases) they existed. For these and other reasons, there is a discussion about the terminology of such a complex. In many sources the term "recreational complex" is used as identical to "tourist-recreational", but at the same time the word recreation with meaning of "restoration", "compensation of health and working capacity of the person" has a priority. The division of the multifunctional recreational complex into three functional groups sounds fair: 1) medical and health-improving (sanatorium-and-spa treatment and rehabilitation); 2) cognitive tourism; 3) economic (regeneration of labor, sphere of economic activity) ${ }^{32}$.

It should be noted that the economic functional grouping of the recreational complex does not really differentiates but rather unites the concepts of tourism and recreation. It is from the standpoint of economic targeting: the tourism should be considered as a special form of recreation, and recreation - as a special form of tourism. Thus, touristic and recreational activities is an area of

31 Semenov V. F. (2008) Reghionaljnyj vymir rekreacijno-turystychnoji dijaljnosti [Regional dimension of recreational and tourist activities]. Odesa: Optymum, pp. 201. (in Ukrainian)

32 Savelieva I. V., Semenov V. F. Navrozova Ju. O. (2019) Orghanizacija ta modeljuvannja procesiv rozvytku ghoteljno-restorannogho biznesu [Organization and modeling of processes in the development of hotel and restaurant business]. Odesa: ONMU. (in Ukrainian) (DOI: https://doi.org/10.31375/978-966-7716-86-8). 
intersection of tourism and recreation, i.e. the simultaneous implementation of actions related to tourism and recreation (while there might be the separate tourism without recreation and recreation without tourism).

The tourist and recreational sphere, as a type of activity, is very selective and is concentrated in certain points of the socio-economic space in the form of separate groups of enterprises with different names and specifics of activity. The development of the tourist and recreational sphere has been conditioned by the radical changes taking place in this sphere since 1991. The almost complete absence of new development priorities, public funding and management system in the early 1990s led to regressive trends and a significant decline in tourism, resort and spa activities. With the overcoming of the socio-economic crisis, changing forms of ownership, sources of funding, management methods, tourism and recreational activities are adapting to market conditions, especially in maritime and coastal tourism.

The priorities for further development of tourism and recreational activities have changed. If earlier the enterprises of resort and recreational sphere were focused on mass recovery of the population's health, now the main direction of their activity is efficiency of rehabilitation process, based on new methods of treatment, improvement, rehabilitation, introduction of the newest technologies of diagnostics and treatment, use of non-traditional methods.

The main topics of current scientific developments remain the rethinking and systematization of existing spatial theories. The main concept that covers all kinds of tourism that occur in a given area is the tourist space, i.e. the space within which tourist phenomena occur. However, for the tourist and recreational complex of Ukraine, including the MEC of the coastal regions of Ukraine, new concepts of spatial organization of tourist activity have not been developed yet.

The Maritime Doctrine of Ukraine emphasizes that the presence of attractive and diverse landscapes, sources of mineral waters and muds create all necessary conditions for the formation of a highly developed industrial recreational and tourist complex within the MEC of Ukraine. However, the medical and health base, as well as especially valuable and unique natural healing resources are not used effectively enough. The material and technical base of recreational and tourist institutions, the range and quality of services do not meet international standards, which reduces the country's competitiveness in the international market of these services. Based on this situation, scientists of the Department of "Entrepreneurship and Tourism" see the strategy of development and stabilization of coastal recreational and tourist destinations in the further intensification of entrepreneurial activity, infrastructure development, science researches in order to return sanatorium activities mainly to treatment and prevention aspects of the health recovery. 
In Ukraine, in this sense, there is a scientific discussion around the scope of the MEC, caused primarily by the need to determine an adequate system of regulation, management and subordination of new organizational entities, taking into account external and internal factors. Most scientists, and with them scientists of the Department of "Entrepreneurship and Tourism" ONMU (I. V. Savelieva, V. F. Semenov, A. M. Ivanov, N. G. Grebenik, Yu. O. Nevrozova, Yu. V. Mikhailova, etc.) believe that the issues of determining the predominant managerial and regulatory influence on the further development of recreation and tourism within the MEC remain unresolved $^{33}$. Given the trends in economics in recent decades, especially in its spatial segment, the management and regulation of the tourism and recreation MEC has long acquired a cluster content. That is, it is proven that the application of the cluster approach allows to achieve the effect of the functioning of the set of economic and social blocks of the basic model of the tourism and recreation sector of the MEC.

\section{TOURISM AS PART OF THE MARITIME CLUSTER OF UKRAINE}

The maritime cluster of Ukraine consists of autonomous modules (subclusters) and has all the possibilities for narrow specialization (Fig. 2). The purpose of creating a maritime cluster is to form a competitive national MEC at the modern technical and technological level, its integration into the world economic system, which is among the major tasks of the Maritime Doctrine of Ukraine.

\section{Special marine economic clusters :}

Fishing

Shipbuliding and shiprepair

Petrochemical

Bioresources

Energy: hydropowe cluster of the sustainable energetics

Transport and logistic cluster

Tourism

Mining and manufacturing industries: microbiology, pharmaceuticals, cosmetics

Industry

Innovations

Source: own research

Fig. 2. Possible ways of marine clusters specialization

33 Ivanov A. M. (2019) Stvorennja ghoteljnogho operatora jak vazhlyva umova rozvytku ghoteljnogho biznesu v Ukrajini [Establishment of a hotel operator as an important condition for the development of the hotel business in Ukraine]. Odesa: Naukovyj visnyk Odesjkogho nacionaljnogho ekonomichnogho universytetu, no. № 1 (264), pp. 73-85. (in Ukrainian) 
As you can see from Fig. 2, a component of the MEC is a tourist subcluster, which consists of basic elements (Fig. 3).

Tourism cluster components inside the MEC
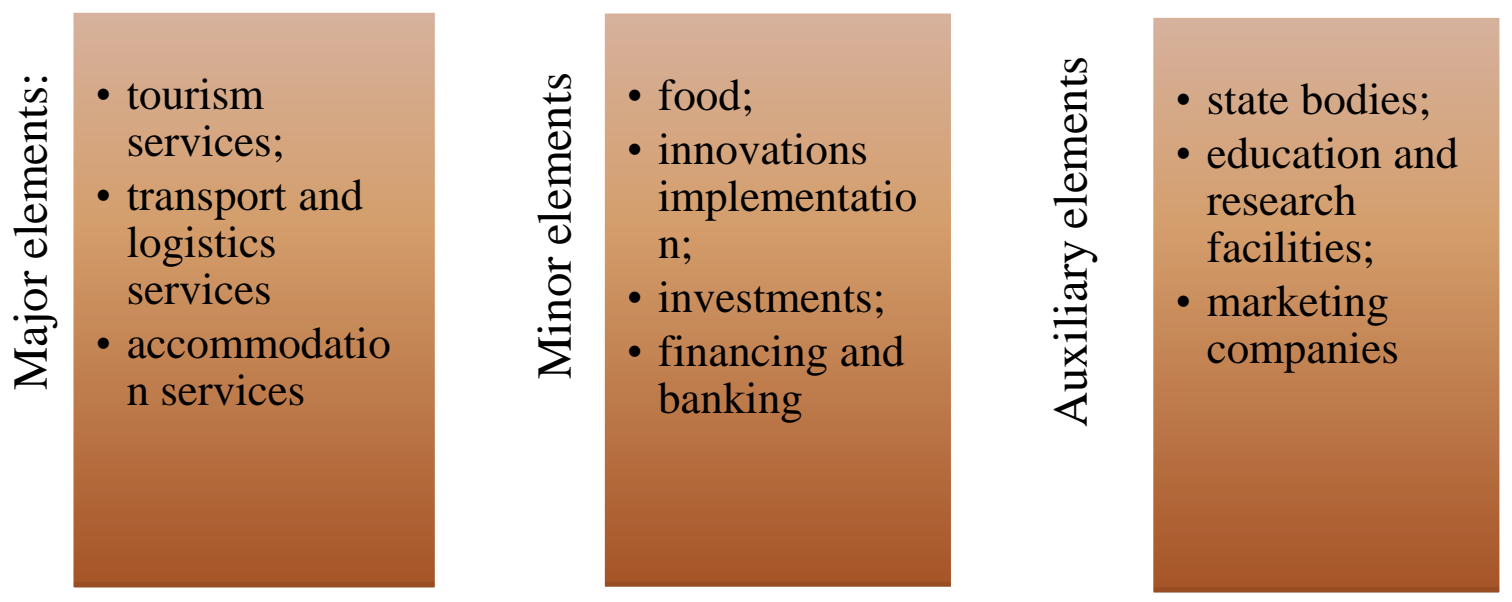

Fig. 3. The main constituent elements

Source: ${ }^{34}$ of the tourism sub-cluster in the maritime cluster

As you can see from Fig. 3, the tourist sub-cluster includes the following main elements: temporary accommodation services, transport and logistic. Auxiliary elements include government institutions, scientific and research organizations, as well as companies that are the main developers of advertising and promotion. Intermediate elements that combine the main and auxiliary elements are additional services - food, hospitality, banks and financial companies, insurance companies, institutions that implement innovation and investment.

The tourist sub-cluster within the MEC unites public administration bodies (standing commissions, committees, departments), maritime business (boards, associations) and public organizations (public councils, committees, individual organizations) and is able to increase the competitiveness of participants and the competitive situation by increasing the number of participants in the tourism sub-cluster, stimulating increased investment, stimulating the development of new business strategies and models.

${ }^{34}$ United Nations Conference of trade and development (2017) Review of Maritime Transport, Geneva: UNCTAD. 
The conceptual advantage of the tourism sub-cluster is the creation of new development opportunities through synergetic effects in the process of an integrated approach to the development of the maritime industry.

Among the main advantages of the formation and operation of the tourist sub-cluster of the MEC in Ukraine for its participants are the following:

- reduction of costs of enterprises-members of the sub-cluster for mobilization of the working capital. This is achieved through the creation of a single distribution base for each activity within the tourism sub-cluster;

- centralization of functions common to the participants of the tourism sub-cluster. In the conditions of fierce competition between the maritime states of the world, the enterprises of the Ukraine's MEC alone are not able to conduct marketing, sociological research, effective economic measures for successful competition against large foreign corporations. Therefore, there is an urgent need for close cooperation of relevant enterprises in the region to accumulate disparate financial, material and labor resources in the conditions of the cluster approach to the development of the MEC of Ukraine and the tourist sub-cluster in it. Given this, the implementation of operational and information-analytical system, integrated automated risk management system, development of modern automated decision support technologies, creation of unified Call-centers, wider introduction of unified electronic document management and management should be immediately considered;

- advantages of using a single infrastructure;

- fuller use of the potential of cooperation and entry into new markets of both individual tourism enterprises and the entire tourism sub-cluster;

- facilitation of obtaining loans for enterprises (travel agencies, hotels, restaurants, tourism agencies, etc.), which are part of the tourism sub-cluster of the maritime cluster;

- concentration of financial flows generated by the assets of the tourism sub-cluster, which operates as part of the maritime cluster, which will be purposefully to modernize the MEC of the country as a whole.

The expected results from the creation of a tourism sub-cluster within the maritime cluster are as follows:

- increase of the tax base;

- increasing the level of employment of the population of the region;

- improving the quality of life of the population of the region;

- GRP growth due to increased competitiveness and labor productivity, involvement of local enterprises in cooperation;

- development of the region's infrastructure;

- restructuring of unprofitable enterprises;

- regulation of investment flows;

- increase of entrepreneurial activity in the region;

- more efficient use of available resources of the region; 
- development of innovative and scientific potential of enterprises in the region;

- improving the information base for statistical research and improving the efficiency of management decisions.

The effective formation of the tourism sub-cluster in the maritime cluster is influenced by a number of factors:

1. Socio-economic: demand for tourism and recreation services and a high level of consumer demand, high level of marketing policy, developed infrastructure: temporary accommodation, restaurant business, shops, medical facilities, entertainment facilities, etc.

2. Technical and technological: developed hospitality infrastructure, transport infrastructure, high level of security of tourist services.

3. Natural and historical-cultural: the presence of natural and anthropogenic objects and territories.

4. Institutional: the presence of regulatory framework, a high level of related industries, effective cooperation of the tourism cluster with the authorities, etc.

Relations between the main participants of the tourism sub-cluster are based on marketing, investment, organizational, production and innovation. Each of these components, uniting around the core of the sub-cluster (port, passenger terminal, university, research institute, etc.), forms a full-fledged interaction from simple to complex multilevel entities at the national, regional and municipal levels.

Marketing activities affect consumer awareness of tourism services in the maritime cluster, as well as form direct and indirect sales channels. The effect of selling a cruise tour is possible only subject to the simultaneous use of marketing services that must be provided when the cruise ship arrives at the port and the services of shipping companies that operate the tour.

The aim of the investment component of the relationship between the subjects of the tourism sub-cluster is to find an investor who is willing to direct its own capital to improve infrastructure, construct or reconstruct the individual facilities that are or may be attractive to tourists and vacationers.

Organizational and production activities are manifested in the joint work of all participants of the tourism sub-cluster in the maritime cluster - from tourists to the port management, or shipping company, individual tourist attractions within the geographical cluster (church, lighthouse, bank, etc.) and customs terminal, zone parking, etc.

Innovative activity - introduction of new forms and methods of management into the activity of business entities.

Based on the above facts, it can be asserted that feasibility of identifying tourism as a promising component of the maritime cluster. The maritime cluster, combining the efforts and finances of the tourism sub-cluster, will 
provide a comprehensive solution to the problems of the maritime complex of Ukraine and will help to increase the competitiveness of coastal regions and Ukraine as a whole, will ensure Ukraine's entry into the ranks of the most powerful maritime states not only due to its geographical and recreational potential, but also in the political, economic, scientific and military spheres.

\section{CONCLUSIONS}

The modern development of tourism in the maritime complex of the coastal regions of the Black and Azov Seas in its scale and importance does not meet the needs of the population and does not fully meet the conditions of optimal functioning. To date, there are no direct mechanisms aimed at developing new forms of management and regulation of tourism. The analysis of theory, as well as world experience, shows that the most effective tool, able to significantly increase competitiveness and improve maritime activities and level of tourism, can be a cluster approach, as one of the basic instruments of organizational and economic mechanism of management and regulation of Ukraine's MEC.

The article substantiates theoretical approaches to detailing the spatial basis of cluster theory, which, in contrast to the sectoral (industrial) interpretation of their essence has become more widespread. It is proven that the concept of the cluster, although it has acquired certain ambiguities and subtexts, and in some cases is limited in application, can be considered as a positive force that continues to exist, develops and be implemented in business practice.

The research of the staff of the "Entrepreneurship and Tourism" Department of ONMU showed that the development and implementation of cluster models is a continuous and consistent process that covers a large cycle of cluster policy and gives a chance to raise tourism to a high level, creating the necessary and sufficient conditions for priority development of the infrastructure and the relevant area of the related services in the maritime complex. The application of the cluster model will solve the following tasks: establish relationships between all stakeholders in the implementation of cluster programs, create a single information space, accelerate the decision-making process in the field of cluster development, increase support for cluster initiatives by entrepreneurs and local authorities.

Among the many ways to implement the cluster idea in practice, the authors propose to create sub-clusters in the maritime complex in stages: on the first stage its needed to clarify the relevance and economic feasibility, mechanisms for creating and developing clusters are developed and tested, and pre-project works are started. The second stage contains the review of 
organizational and legal issues of creation and functioning of clusters. At the third stage, priority clusters are adjusted, forms and methods of state support are selected, and a complete package of organizational documents is also developed.

In general, the implementation of the reflections and recommendations presented in the paper will in some way affect the regional cluster policy of the coastal regions of the Black and Azov Seas.

\section{SUMMARY}

The article assesses the current state and outlines the state priorities for the development of the maritime complex of Ukraine. It has been proved that it is stagnant - a state of crisis, when there is a structural deformation, violation of technological relationships and proportions between industry components and their degradation, the threat of bankruptcy for many economic entities of the maritime complex. The world experience of managing the development of the maritime complex is characterized, which allowed us to clarify the strategic directions of the MEC development.

The article reviews the peculiarities of the development of the tourist and recreational complex as a component of the MEC, which today retains high potential, but requires serious public and private investment, management reform, the use of new organizational and innovative forms of regulation aimed at development, as well as conservation, restoration and reproduction of coastal zones of natural resources and waters of the Azov and Black Seas.

The place, advantages and expected results from the creation of a tourist sub-cluster within the maritime cluster are revealed.

\section{REFERENCES}

1. Semenov V. F., Baldzhy M. D., Mozghaljova V. M. (2008) Reghionaljnyj vymir rekreacijno-turystychnoji dijaljnosti [Regional dimension of recreational and tourist activities]. Odesa: Optimum, pp. 201. (in Ukrainian)

2. Semenov V. F., Bilegha O. V. (2014) Konkurentni perevaghy merezhevykh struktur klasternogho typu [Competitive advantages of clustertype network structures]. Odesa: Atlant VOISOIU, pp. 236. (in Ukrainian)

3. Semenov V. F., Basjuk O. V. (2014) Terytorialjni umovy i strateghiji rozvytku turyzmu $\mathrm{v}$ reghionakh [Territorial conditions and strategies for the development of tourism in the regions]. Odesa: Visnyk ONU im. I. I. Mechnikova, no. 19 (1/2), pp. 78-81. (in Ukrainian)

4. Semenov V. F . (2010) Klasterna polityka v upravlinni reghionaljnym rozvytkom turyzmu [Cluster policy in the management of regional tourism development]. Odesa: Visnyk socialjno-ekonomichnykh doslidzhenj, no. 40, pp. 56-63. (in Ukrainian) 
5. Semenov V. F., Mozghaljova V. M., Davydenko I. V. (2006) Reghionaljnyj rekreacijnyj klaster u konteksti strukturnoji perebudovy ekonomiky [Regional recreational cluster in the context of structural perestroika economy]. Odesa: Reghionaljna ekonomika, no. 3, pp. 78-89. (in Ukrainian)

6. Semenov V. F. (2008) Reghionaljna ekonomika [Regional economics]. Kyiv: Lesja. (in Ukrainian)

7. Semenov V. F. (2010) Klasterna polityka v upravlinni reghionaljnym rozvytkom turyzmu [Cluster policy in the management of regional tourism development]. Odesa: Visnyk socialjno-ekonomichnykh doslidzhenj, no. 40, pp. 52-57. (in Ukrainian)

8. Kotlubaj O. M. (2015) Portovyj kompleks Ukrajiny: problemy i perspektyvy rozvytku [Port complex of Ukraine: problems and prospects of development]. URL: http://www.2000.ua/vnomere/derzhava/resursy/portovijkompleks-ukraini-b3-1- b4_1440057128.htm (accessed 28 May 2020).

9. Kotlubaj A. M. (2008) Torgovoe sudokhodstvo Ukrainy: problemy i perspektivy [Merchant shipping of Ukraine: problems and prospects]. Odessa: IPRI NAN Ukrainy, pp. 256. (in Ukrainian)

10. Dergachev V. A. (2004) Geopolitika [Geopolitics]. Moscow: YuNITIDANA (in Russian)

11. Savelieva I. V. (2019) Rozvytok krujiznogho turyzmu v umovakh vykorystannja metodyky smart-specializaciji Odesjkoji oblasti [Development of cruise tourism in the conditions of using the technique of smart specialization of Odessa region]. Odessa: Rozvytok metodiv upravlinnja ta ghospodarjuvannja na transporti, no. 4(69), pp. 5-14. (in Ukrainian) (DOI https://doi.org/10.31375/2226-1915-2019-4-5-14)

12. Mykhajlova Ju. V. (2012) Otsenka privlekatel'nosti portov zakhoda v kruiznom marshrute [Assessment of the attractiveness of ports of call on a cruise route]. Odessa: Rozvytok metodiv upravlinnja ta ghospodarjuvannja na transporti, no. 14, pp. 113-128. (in Ukrainian)

13. Mykhajlova Ju. V. (2013) Vliyanie morskoy turisticheskoy renty na formirovanie dokhodov kruïznogo operatora [Vliyanie morskoy turisticheskoy renty na formirovanie dokhodov kruïznogo operatora]. Odessa: Rozvytok metodiv upravlinnja ta ghospodarjuvannja na transporti, no. 1(20), pp. 28-45. (in Ukrainian)

14. Ivanov A. M. (2012) Upravlinnja konkurentospromozhnistju rekreacijno-ozdorovchogho zemlekorystuvannja [Management of the competitiveness of recreational and health-improving land use]. Mykolajiv: Dyzajn ta Polighrafija, pp. 248. (in Ukrainian) 
15. Ivanov A. M. (2018) Instytucionaljni aspekty rekreacijnogho zemlekorystuvannja [Institutional aspects of recreational land use]. Lucjk: Ekonomichnyj forum, no. 2, pp. 178-182. (in Ukrainian)

16. Ivanov A. M. (2013) Osoblyvosti upravlinnja rekreacijnoozdorovchymy pidpryjemstvamy $\mathrm{v}$ systemi turystychnogho klasteru [Features of management of recreational and health-improving enterprises in the system of tourist cluster]. Odessa: Ekonomika pishchevoy promyshlennosti, no. 4(20), pp. 12-17. (in Ukrainian)

17. Ivanov A. M. (2018) Shljakhy udoskonalennja instytucionaljnogho mekhanizmu rekreacijno-turystychnoji polityky Ukrajiny [Shljakhy udoskonalennja instytucionaljnogho mekhanizmu rekreacijno-turystychnoji polityky Ukrainy]. Kherson: Biznes-navighator, no. 1(44). pp. 72-76. (in Ukrainian)

18. Ivanov A. M. (2019) Instytucionaljni zasady vzajemodiji sub'jektiv rynku morsjkogho krujiznogho turyzmu [Institutional principles of interaction between the subjects of the maritime tourism market]. Odessa: Development of methods of management and administration of transport, no. 3(68), pp. 100-112. (in Ukrainian) (DOI https://doi.org/10.31375/2226-1915-2019-3-97-107).

19. Kholodenko A. M. (2002) Modeljuvannja cinovoji konkurenciji transportnykh pidpryjemstv u loghistychnij systemi [Modeling of price competition of transport enterprises in the logistics system]. Kharkiv: KhNADU, no. 5, pp. 37-41. (in Ukrainian)

20. Kholodenko A. M., S. V. Meljnykov (2006) Taryfnoe reghulyrovanye loghystycheskoj cepochky postavok [Tariff regulation of the supply chain]. Odesa: Metody ta zasoby upravlinnja rozvytkom transportnykh system, no. 11, pp. 17-40. (in Ukrainian)

21. Ghrebenyk N. Gh. (2008) Koncepcyja klasterov na morskom transporte [The concept of clusters on maritime transport]. Odesa: Rozvytok metodiv upravlinnja ta ghospodarjuvannja na transporti, no. 8, pp. 86-93. (in Ukrainian)

22. Ghrebenyk N. Gh. (2013) Osnovy realizatsii klasternoy kontseptsii v morekhozyaystvennom komplekse Ukrainy [Basics of the implementation of the cluster concept in the maritime complex of Ukraine]. Odesa: Rozvytok metodiv upravlinnja ta ghospodarjuvannja na transporti, no. 1(42), pp. 45-55. (in Ukrainian)

23. Navrozova Ju. O. (2004) Metodы upravlenyja kachestvom portovoj produkcyy [Methods of quality management of port products]. Odesa: Rozvytok metodiv upravlinnja ta ghospodarjuvannja na transporti, no. 18, pp. 70-83. (in Ukrainian)

24. Navrozova Yu. O. (2017) Upravlinnja vytratamy na jakistj jak skladova koncepciji strateghichnogho upravlinnja vytratamy portovogho operatoru [Quality cost management as a component of the concept of strategic cost 
management of the port operator]. Kharkiv: Problemy i perspektyvy rozvytku pidpryjemnyctva, no. 3(2), pp. 31-36. (in Ukrainian)

25. Morsjka doktryna Ukrajiny na period do 2035 roku (2016) [Maritime Doctrine of Ukraine for the period up to 2035]. URL: http://sudostroy.com/category/morskaja-doktrina-ukrainy/ (accessed 29 May 2020).

26. Ministerstvo vnutrishnikh sprav posyljuje robotu svojikh pidrozdiliv na diljanci Azovo-Chornomorsjkogho basejnu [The Ministry of Internal Affairs strengthens the work of its units in the Azov-Black Sea basin]. URL: http:// www.ukrinform.ua/rubric-ato/2686515-mvs-posilue-prisutnist-v-azovskomuta-cornomu-morah.html (accessed 29 May 2020).

27. Velyke perebalansuvannja [Great rebalancing]. URL: https://tyzhden.ua/Economics/234522 (accessed 29 May 2020).

28. Volosjuk M. V., Vdovychenko L. Ju. (2016) Funkcionaljna struktura moreghospodarsjkogho kompleksu Ukrajiny [Functional structure of the maritime economic complex of Ukraine]. Kharkiv: Biznes Inform, no. 2, pp. 14-20. (in Ukrainian)

29. Ivanov A. M. (2018) Innovacijna dijaljnistj jak skladova konkurentospromozhnosti pidpryjemstv restorannogho ghospodarstva [Innovative activity as a component of competitiveness of restaurant enterprises]. Proceedings of the Jevropejsjka integhracija: istorychnyj dosvid ta ekonomichni perspektyvy, Odesa: ONU im. I. Mechnykova, pp. 44-46.

30. Kotlubaj O. M. Ekonomichni mekhanizmy rozvytku torghiveljnogho moreplavannja $\mathrm{v}$ Ukrajini [Economic mechanisms for the development of merchant shipping in Ukraine]. Odesa: IPREE D NAN Ukrajiny, pp. 453. (in Ukrainian)

31. Granberg A. G. (2004) Osnovy regional'noy ekonomiki [Fundamentals of regional economy]. Moscow: GU VShE, S. 41. (in Russian)

32. Semenov V. F. (2008) Reghionaljnyj vymir rekreacijno-turystychnoji dijaljnosti [Regional dimension of recreational and tourist activities]. Odesa: Optymum, pp. 201. (in Ukrainian)

33. Savelieva I. V., Semenov V. F. Navrozova Yu. O. (2019) Orghanizacija ta modeljuvannja procesiv rozvytku ghoteljno-restorannogho biznesu [Organization and modeling of processes in the development of hotel and restaurant business]. Odesa: ONMU. (in Ukrainian) (DOI https://doi.org/10.31375/978-966-7716-86-8).

34. Ivanov A. M. (2019) Stvorennja ghoteljnogho operatora jak vazhlyva umova rozvytku ghoteljnogho biznesu v Ukrajini [Establishment of a hotel operator as an important condition for the development of the hotel business in Ukraine]. Odesa: Naukovyj visnyk Odesjkogho nacionaljnogho ekonomichnogho universytetu, no. № 1 (264), pp. 73-85. (in Ukrainian) 
Information about the authors:

Savelieva I. V.,

Doctor of Economics, Professor, Head of the Department "Entrepreneurship and Tourism",

Odessa National Maritime University

34, Mechnikov str., Odesa, 65029, Ukraine

ORCID ID: orcid.org/0000-0002-6492-2130

Semenov V. F., Doctor of Economics, Professor at the Department "Entrepreneurship and Tourism", Odessa National Maritime University 34, Mechnikov str., 65029, Ukraine ORCID ID: orcid.org/0000-0003-2642-9393

Ivanov A. M., Candidate of Economics Sciences, Associate Professor at the Department "Entrepreneurship and Tourism", Odessa National Maritime University 34, Mechnikov str., Odesa, 65029, Ukraine ORCID ID: orcid.org/0000-0002-7691-3012 